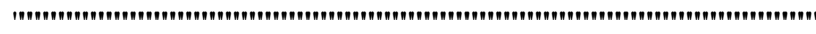

В. В. Редько

Дніпропетровський національний університет

\section{ЕКОЛОГІЧНІ ОСОБЛИВОСТІ ТА БІОІНДИКАЦІЙНЕ ЗНАЧЕННЯ ЧЕРЕПАШКОВИХ АМЕБ (TESTACEA, RHIZOPODA) У ПРИРОДНИХ I АНТРОПОГЕННО ТРАНСФОРМОВАНИХ БІОГЕОЦЕНОЗАХ}

\begin{abstract}
Проаналізовано фізіологічні та екологічні особливості черепашкових амеб Testacea, Rhizopoda. Підкреслено, що тестації можуть виступати біоіндикаторами різноманітних грунтових умов у природних біогеоценозах. Наведено дані з використання представників надкласу Rhizopoda як показників антропогенного впливу на грунти.
\end{abstract}

The literature data on physiology and ecology characteristics of testate amoebas Testacea, Rhizopoda were reviewed. The testate amoebas can be used as the bioindicators of the different soil conditions in natural biogeocenoses. The data of using the superclass Rhizopoda members as indicators of anthropogenic influences on soil are given.

\section{Ветуп}

Черепашкові амеби - одна 3 найпоширеніших груп грунтової біоти, яка присутня майже в усіх грунтових біоценозах Земної кулі [44; 60]. Testacea беруть активну участь у трансформації органічної речовини. Експериментально доведено, що ряд форм руйнує лігнін і целюлозу, виступаючи первинними деструкторами рослинного опаду [54; 56]. У сукцесійному ряду деструкторів целюлози тестації сприяють лізису грибного міцелію та прискорюють продукування аміаку у грунті [6].

Тестації - амебоїдні організми, які будують однокамерну черепашку з отвором (псевдостомом) для виходу псевдоподій. Черепашки різноманітні за формою. Їх морфологія має тісний зв'язок із властивостями біотопу, зокрема із рівнем зволожен-

[(C) В. В. Редько, 2007 
ня. Але численні види, підвиди та форми перебувають у певних межах природної мінливості $[47 ; 59 ; 71 ; 73]$. Морфологія черепашок залежить від природи субстрату. Будівельний матеріал також може відрізнятися. Форма та розмір ідіосом, наприклад, залежать від об'єктів живлення амеб. Черепашки - це своєрідні посередники між організмом і середовищем, що акумулюють екологічні впливи на популяцію [55].

Мета даної роботи - виявити екологічні особливості та біоіндикаційне значення черепашкових амеб (Testacea, Rhizopoda) у природних і антропогенно трансформованих біогеоценозах.

\section{Фізіологічні особливості та біоіндикаторні властивості тестацій}

Черепашкові амеби (Testacea), які населяють грунт, фізіологічно залишаються водними організмами, але значно меншими за розміром від справжніх гідробіонтів [5; 6; 15]. За даними Ю. Г. Гельцера, розміри грунтових тестацій - від 15-20 до 120170 мкм. Найбільшу черепашку має рідкісний вид - Bullinularia indica Penard, 1907. Найчастіше ж зустрічаються дві розмірні категорії - 20-40 та 60-80 мкм [8]. Ці організми мають значне видове та екологічне різноманіття, досягають високої кількості у верхніх шарах грунту.

Черепашкові амеби заселяють плівки та скупчення вологи на твердих частках, у тонких порах і капілярах. Проблема розмірних характеристик «мікробіотопу» М. С. Гіляровим частково розглядається у контексті біоіндикації грунту: “... існуючі у грунті різні розмірні групи грунтових безхребетних перебувають ніби у різних середовищах, у представників кожної розмірної групи ніби-то свій особливий навколишній світ" [27]. Індикаційне значення найпростіших визначається фізико-хімічними характеристиками грунтових розчинів ( $p H$, склад водорозчинних солей, окисновідновні умови, особливості органічної речовини тощо). Стан рівноваги у системі «тверда фаза грунту - грунтовий розчин» досягається рідко, тому умови середовища існування для нанофауни мінливіші, ніж для грунтової мікро- та мезофауни [3]. За даними M. J. Swift [65] зі співавторами, існують підтвердження потенційного впливу глобальних змін (температури, концентрації двоокису вуглецю та порушення грунтового шару) на склад і різноманіття грунтової біоти. Також ці фактори впливають і на кругообіг нітрогену та інших хімічних речовин.

За даними J. Stout [64], щорічні повені призводять до збагачення педофауни водними видами найпростіших. Відмінність фауни на ділянках із надмірним тривалим зволоженням і на тих, що не затоплюються, демонструє біодіагностичні властивості тестацій як показників грунтових умов [45]. Тривале перебування під водою підтоплених ділянок заплавних лук та діброви прируслового валу викликає розширення набору екологічних груп тестацій за рахунок гідрофілів, порівняно з луками та листяними лісами зі звичайним рівнем зволоження [17].

Існують дані [5], що протисти виявляють стійкість до високих концентрацій солей у грунті. Під захистом цист вони можуть протистояти засоленню протягом десятиріч. При зниженні концентрації солей інцистовані найпростіші переходять у активний стан, вказуючи таким чином на ступінь і характер «активності» грунту після промивки [4]. Встановлено [18], що умови засолення переносять лише деякі види черепашкових амеб - Centropyxis halophila Bonnet, 1959, Plagiopyxis minuta Bonnet, 1959. Найбільший вплив (у зв'язку 3 підвищеною розчинністю) має $\mathrm{Na}_{2} \mathrm{SO}_{4}$. Дослідження Szabo зі співавторами [5] показали, що спостерігається тісний зв'язок між фізичними, хімічними властивостями грунту та морфофізіологічним станом найпростіших. У засолених грунтах джгутикові та корененіжки мають широку екологічну варіацію, у той час як інфузорії повністю відсутні. 
Тестації - цінні біоіндикатори різноманітних грунтових [43; 44] і прісноводних [57] умов. Уздовж грунтового профілю відбувається певна зміна видів і форм черепашкових амеб, тому за цією групою найпростіших можна дізнатися про зміни багатьох біотичних i абіотичних чинників. Завдяки наявності черепашки тестації легше підраховуються. Грунтові горизонти різняться за екологічними характеристиками та ступенем неоднорідності. Розміри “мікроареалу" для нанофауни визначаються фактором неоднорідності грунту або його горизонтальною та вертикальною анізотропністю. [3]. Встановлено, що чим жорсткіші вимоги висуває середовище, тим чіткішими стають адаптації до нього і тим менша кількість форм відповідає цим вимогам [18].

За розташуванням субфосильних залишків черепашок у шарах грунту можна встановити умови існування. Наприклад, у болоті протягом усього його розвитку можна визначити межі сухих і вологих ділянок, окремі етапи заболочування [18]. Дані кластерного аналізу підтверджують відмінності угруповань тестацій у горизонтах грунту та, відповідно, внутрішньопрофільні особливості вертикального розподілу черепашкових амеб [3].

L. Bonnet i R. Thomas [33] виявили функціональну залежність поширення тестацид від фізико-хімічних характеристик грунту, проміжні типи якого населені Geopyxella та Pseudawerintzevia. Вузьку специфічність до лужних грунтів виявляють Arcella arenaria Greeff, 1866, Bullinularia indica Penard, 1907, Heleopera petricola v. humicola Bonnet \& Thomas, 1955, Trigonopyxis arcula Penard, 1907. Представники Hyalosphenia subflava Cash, 1909 надають перевагу кислим лісовим грунтам. Порівняння верховинних $(p H 3,2-4,6)$ та низових $(p H>5,0)$ боліт Англії також виявили розбіжності у фауні черепашкових амеб [18]. Centropyxys laevigata Penard, 1890 існують у грунтах, багатих на гумус, а $C$. minuta Deflander, 1929 - у скелетних грунтах. Таким чином, фауна молодих «незрілих» грунтів складається переважно 3 представників родини Centropyxidae [48], а зональних або «зрілих» грунтів - із представників родини Plagiopyxidae [18]. Навіть незначні розбіжності за типами гумусу, які часто становлять проблему при ідентифікації умов класичними методами, можуть бути виявлені шляхом дослідження угруповань черепашкових амеб. Існують результати дослідів [15], які свідчать, що незначне збільшення щільності грунту призводить до гальмування росту популяцій найпростіших.

На підставі дослідження особливостей будови черепашок L. Bonnet запропонував класифікацію морфотипів Testacea. Була встановлена залежність між морфологією черепашки та властивостями біотопу [30; 34]. Для тестацид-педобіонтів характерне надбання плагіостомії та криптостомії - зміщення псевдостома на вентральний бік, зменшення його розмірів, утворення камери, яка відіграє роль буфера між зовнішнім середовищем і організмом. Чіткіше ці адаптивні особливості морфології черепашки виражені у родин Centropyxidae та Plagiopyxidae - основних представників гумусового горизонту [18]. W. Schönborn відносить усі плагіостомні та криптостомні види до справжніх геобіонтів [55].

Початок систематичним дослідженням видового складу та розповсюдження амеб і застосування цих даних для діагностики грунтових умов поклали роботи L. Bonnet [30-33]. Застосування багатофакторного аналізу сприяло виявленню функціональної залежності поширення Testacea від фізико-хімічних характеристик грунтів. Характерними для більшості грунтів є Geopyxella sylvicola Bonnet \& Thomas, 1955, Pseudawerintzewia calcicola Bonnet, 1959, Centropyxis halophila Bonnet, 1959 [39; 55]. Вертикальне розташування, 3 погляду D. Chardez [38], тісно пов'язане 3 типом грунту та може слугувати навіть чутливішим його індикатором, ніж видове різноманіття. Неодноразово відмічалося, що основна маса черепашкових амеб зосе-

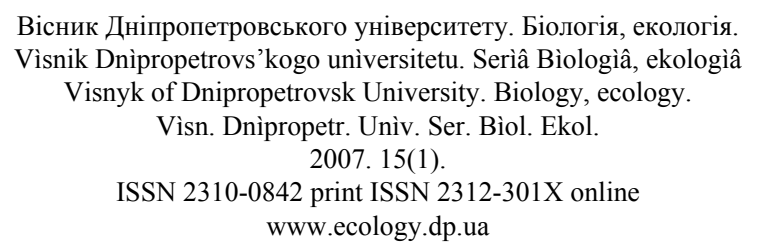


реджена у верхніх горизонтах (підстилці або дерновому горизонті). Мінеральні горизонти, як правило, бідніші за видовим складом і чисельністю. Також помічено, що тестації чисельніші в органогенних горизонтах хвойних лісів порівняно з листяними [55]. У хвойних лісах спостерігається розвиток потужної підстилки, що сприяє формуванню багатої фауни черепашкових амеб $[5 ; 17]$. Зменшення видового складу та чисельності тестацій з глибиною пов'язане зі зменшенням концентрації доступного кисню, ущільненням грунту. Негативну роль також можуть відігравати процеси оглеєння, особливо у заплавних грунтах [17].

На думку К. Б. Гонгальского, просторовий розподіл педобіонтів впливає на прояви грунтової активності в екосистемах [14]. Розподіл грунтових тварин досліджують для встановлення зв'язків із факторами середовища, коректної оцінки популяційних параметрів [50], індикації певних властивостей грунту [12]. Ступінь аридності умов грунтоутворення можна діагностувати за способом утворення цист [11].

Черепашки Testacea зберігаються у торфі та озерних відкладеннях протягом тривалого часу [37]. У ході експедиції на півострів Биковський А. А. Бобровим та співавторами проведене вивчення складу грунтових угруповань черепашкових амеб пізньоплейстоценового та голоценового періодів як біоіндикаторів четвертинних багаторічномерзлих відкладень. Результати дослідження дали змогу порівняти палеокліматичні особливості плейстоцену та голоцену. У пробах, датованих близько 53 тис. років, присутні черепашкові амеби, характерні для мінеральних боліт, домінують еврибіонтні та грунтові види. Значний відсоток складають представники кальцефільного виду Centropyxis plagiostoma Bonnet \& Thomas, 1955. Для періоду близько 45-43 тис. років тому були характерні представники родів Arcella, Centropyxis, Cyclopyxis, Plagiopyxis, Argynia, які у теперішній час зустрічаються переважно у сфагнових мохах і на кислих грунтах із підвищеною вологістю [28]. M. Wolf дав опис Arcella sp., знайденої у Німеччині у бітумі пізнього кам'яновугільного періоду [74]. Тестації, подібні до Pontigulasia та Cyphoderia, виявлені в янтарі середини крейдяного періоду з Канзаса та Домініканської республіки [69; 70]. У відкладеннях (віком 15 млн. років) вулканічного кратерного озера знайдено Euglypha crenulata Wailes, 1912 та E. scutigera Penard, 1911. Ці викопні види, які існують донині, тепер віднесені до роду Scutiglypha [46].

Зазвичай чисельність і видове різноманіття тестацій оцінюють за всією сукупністю черепашок, знайдених у грунтовій суспензії. У цю сумарну кількість входять живі організми - трофічно активні форми, інцистовані клітини, а також порожні черепашки. Кількість останніх значно перевищує рівень чисельності живих клітин. Як показують досліди, чисельність особин, що активно живляться, не перевищує 25 \% від загальної кількості черепашок [54]. В умовах експерименту деструкція порожніх черепашок еугліф триває три місяці [58]. Але лабораторні експерименти 3 дослідження швидкості розкладання порожніх черепашок показали, що вона повинна складати 1-2 тижні. Природний шлях їх розкладання може змінити жорстка термічна обробка грунтових зразків [51]. Накопичення порожніх черепашок збільшується у грунтах із гумусом типу мор. У підстилках, які формуються на таких грунтах, тестації зустрічаються у найбільшій кількості [54]. Сукупність порожніх черепашок у грунтах формує некроценоз або палеоценоз [3; 54]. При дослідженні торф'яних відкладень верхових боліт W. Schönborn використовував метод ризоподного аналізу - вивчення складу некроценозу [55].

\section{Черепашкові амеби антропогенно трансформованих грунтів}

У країнах із високим рівнем урбанізації грунти потерпають від техногенного впливу. Забруднення грунту пестицидами та важкими металами спостерігається че-

Вісник Дніпропетровського університету. Біологія, екологія.

Vìsnik Dnìpropetrovs'kogo unìversitetu. Serîa Bìologîâ, ekologiâ Visnyk of Dnipropetrovsk University. Biology, ecology. Vìsn. Dnìpropetr. Unìv. Ser. Bìol. Ekol. 2007. 15(1).

ISSN 2310-0842 print ISSN 2312-301X online www.ecology.dp.ua 
рез накопичення відходів промисловості та комунального господарства. Вивчаючи вертикальне розташування Testacea у шарах грунту, можна встановити склад забруднення та рівень антропогенного впливу (наприклад, агроценозів). Ю. Г. Гельцером із співавторами встановлено, що комплекси черепашкових амеб під лісом, пасовищами та ріллею суттєво різнилися за видовим складом і чисельністю. Максимальне різноманіття видів спостерігається в лісі, мінімальне - на ділянці ріллі [5; 7]. Чим більший антропогенний вплив на природний грунтовий покрив (особливо верхній підстилковий або дерновий шар), тим вужчий спектр морфологічних типів Testacea, що його населяють. Це дозволяє використовувати черепашкових амеб для оцінки різного ступеня окультуреності грунтів.

У деяких країнах Європи виконуються заходи з рекультивації порушених земель і шахтних відвалів. Ю. Г. Гельцером [10] при аналізі штучних грунтів у свіжій шахтній породі (алевроліти та аргіліти) найпростіші не виявлені. Кам'яне вугілля залягає в районі заплави річок. Унаслідок його видобування спостерігається підтоплення лісових і сільськогосподарських угідь, викиди шахтних вод, що мають високий вміст солей і негативно впливають на довкілля. Вивчення G. Olschowy [52] та W. Pflug [53] видового складу у породах і підстилці насаджень старих (понад 40 років) шахтних відвалів показало, що із 48 таксонів домінують Centropyxis sphagnicola Deflandre, 1929, Corytion dubium Taranek, 1882, Euglipha rotunda Wailes \& Penard, 1911, Phryganella acropodia (Hertwig \& Lesser, 1874), Trinema complanatum Penard, 1890, T. lineare Penard, 1890. Структура скупчень черепашкових амеб залежить від віку та типу підстилки. Тестацій реєструють також у інших порушених умовах навколишнього середовища та субстратах із високим вмістом мінералів, тобто у грунтах після лісових пожеж [35], вулканічній тефрі [61], грунті антарктичної пустелі [40], відвалах вугільних шахт [72]. Найчастіше зустрічаються види Corythion dubium Taranek, 1882, Euglipha rotunda Wailes \& Penard, 1911, Centropyxis aerophila Deflandre, 1929. Ці види також зустрічаються у стічних водах, шарах дорожніх і тротуарних покриттів, які складаються з граніту, геотекстильного поліпропілену та бетону [62].

Важкі метали потрапляють у грунт разом зі стічними водами заводів [66] та пестицидами [68]. Важкі метали промислового походження можуть досягати надзвичайно високих концентрацій у грунті [49; 66]. Основними важкими металами, що визначають рівень сумарного забруднення грунту, $є$ хром, марганець, свинець, ванадій. У місцях перевищення ГДК цих елементів утворюються великі зони санітарногігієнічних аномалій [19; 22]. За даними А. Tsyganov та Y. Mazei, Arcella gibbosa Penard, 1890 - еврибіонтний вид, який може існувати у токсичних умовах [67].

Досліджуючи вплив пестицидів на грунтових найпростіших, Ю. Г. Гельцер [13] встановив, що у перші 10 діб після обробки полів діуроном спостерігається зменшення чисельності найпростіших, а до тридцятої доби фауна відновлюється.

Осад відходів комунального господарства - багатокомпонентний комплекс хімічних сполук [20]. Біотестування застосовується для оцінки екологічного стану природних умов, що дає змогу досить повно дослідити вплив осаду стічних вод на біоту. До складу тест-систем входить комплекс найпростіших і бактерій, який контактує із забруднюльними речовинами [24].

Нафтові вуглеводні - один із найпоширеніших полютантів водної екосистеми. Потрапляючи у водойми, вуглеводні трансформуються під впливом фізико-хімічних і біологічних факторів, i, одночасно, акумулюються в клітинах гідробіонтів різних трофічних рівнів. Бактерії - основні агенти, що здійснюють розкладення нафтових вуглеводнів [25]. При дослідженні трофічного ланцюга «бактерії - окисники нафтових вуглеводнів - інфузорії» спостерігається перехід алканів від прокаріотів до найпростіших [16].

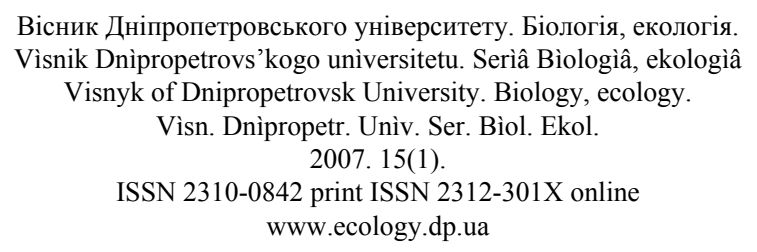


Особливість міських грунтів - високий вміст рухливого та обмінного $\mathrm{Na}$. Максимальні концентрації даного елемента спостерігаються у підстилці паркових грунтів i гумусо-акумулятивній частині грунтового профілю. Цей елемент може пригнічувати розвиток мікроорганізмів, грунтових тварин і рослинного покриву. Унаслідок накопичення обмінного $N a$ погіршується процес деструкції опаду, що негативно впливає на гумусоутворення [21].

Protozoa - найважливіший компонент грунтових екосистем, який має значну вагу в загальній продукції екосистем. Зміни динаміки грунтотвірного процесу та антропогенні фактори значно впливають на якісні та кількісні показники грунтової біоти. Найпростіші мають тендітну зовнішню мембрану, тому реагують на зміни навколишнього середовища швидше, ніж будь-який інший еукаріотичний організм. Морфологічні, екологічні та генетичні відмінності найпростіших із різних географічних зон мінімальні.

\section{Висновки}

Testacea відносяться до активних трансформаторів органічної речовини (беруть участь у руйнуванні целюлози та лігніну). Фізіолого-екологічні особливості черепашкових амеб зумовлені їх існуванням у плівках, скупченнях вологи на твердих частках і в тонких капілярах грунту. Тестації виявляють функціональну залежність від фізико-хімічних характеристик грунтів. Фауна «незрілих» грунтів складається переважно з представників родини Centropyxidae, а зональних, або «зрілих» грунтів із представників родини Plagiopyxidae. Дослідження угруповань тестацій також використовується у палеонтології.

На основі поширених видів Protozoa розроблені тест-системи для визначення впливу забруднювальних речовин у лабораторних і польових умовах. До складу тестсистем входять найпростіші, інколи у комплексі з бактеріями. Черепашкові амеби можуть бути індикаторами таких антропогенних впливів, як ступінь порушеності та окультуреності грунту, накопичення пестицидів i важких металів, багатокомпонентних відходів комунального господарства та викидів промислових об'єктів.

\section{Бібліографічні посилання}

1. Аристовская Т. В. Микробиология процессов почвообразования. - Л.: Наука. $-1980 .-189$ с.

2. Бабьева И. П. Практическое руководство по биологии почв / И. П. Бабьева, Н. С. Агре. М.: МГУ, 1971. - 140 с.

3. Бобров А. А. Историческая динамика озерно-болотных экосистем и сукцессии раковинных амеб (Testacea) // Зоологический журнал. - 2003. - Т. 82, № 2. - С. 215-223.

4. Бродский А. Л. Protozoa почвы и их роль в почвенных процессах // Бюлл. Среднеаз. гос. ун-та. - 1935. - № 3. - С. 99-181.

5. Гельцер Ю. Г. Адаптация простейших к жизни в почве и их индикационное значение / Ю. Г. Гельцер, Г. А. Корганова // Протозоология. - 1980. - № 5. - С. 36-51.

6. Гельцер Ю. Г. Почвенные простейшие как компонент биогеоценоза / Ю. Г. Гельцер, Р. Р. Ибадоа, Г. Д. Мордкович // Протозоология. - 1980. - № 5. - С. 21-35.

7. Гельцер Ю. Г. Влияние окультуренности почв на фауну раковинных корненожек (Protozoa, Testacida) / Ю. Г. Гельцер, А. С. Яковлев // Фауна и экология почвенных беспозвоночных Московской области. - М.: Наука, 1983. - С. 156-162.

8. Гельцер Ю. Г. Биологическая диагностика почв. - М.: МГУ, 1986. - 80 с.

9. Гельцер Ю. Г. Раковинные амебы окультуренных дерново-подзолистых почв // Микроорганизмы в сельском хозяйстве. Тез. докл. ІІІ Всесоюзн. конф. - М.: МГУ, 1986. - С. 61.

10. Гельцер Ю. Г. Исследования раковинных амеб в ненарушенных образцах почвы // Совр. пробл. протозоол. Тез. докл. IV Всесоюзн. съезда ВОПР. - Л.: Наука, 1987. - С. 59.

Вісник Дніпропетровського університету. Біологія, екологія.

Vìsnik Dnìpropetrovs'kogo unìversitetu. Serìa Bìologiâ, ekologîâ Visnyk of Dnipropetrovsk University. Biology, ecology. Vìsn. Dnìpropetr. Unìv. Ser. Bìol. Ekol. 2007. 15(1).

ISSN 2310-0842 print ISSN 2312-301X online www.ecology.dp.ua 
11. Гельцер Ю. Г. Динамика биологической активности крайне аридных почв Монгольской Народной Республики // Биодинамика почв. Тез. III Всесоюзн. симпоз. - Таллин, 1988. - С. 9.

12. Гельцер Ю. Г. Раковинные амебы (Testacida, Protozoa) в почвах / Ю. Г. Гельцер, Г. А. Корганова, Д. А. Алексеев // Генезис и экология почв Центрально-лесного государственного заповедника. - М.: Наука, 1979. - С. 197-229.

13. Гельцер Ю. Г. Влияние пестицидов на почвенных простейших / Ю. Г. Гельцер, В. А. Гептнер // Протозоология. - 1980. - № 5. - С. 143-152.

14. Гонгальский К. Б. Пространственное распределение животных и изменчивость трофической активности, измеренной при помощи bait-lamina test, в дерново-подзолистой почве под ельником / К. Б. Гонгальский, А. Д. Покаржевский, Ф. А. Савин // Экология. - 2003. № 6. - C. 434-444.

15. Жуков О. В. Основи грунтової зоології та біоіндикації / О. В. Жуков, О. Ф. Пилипенко, С. М. Кірієнко. - Д.: ДНУ, 2002. - 72 с.

16. Каретникова Е. А. Миграция $n$-алканов дизельного топлива по трофической цепи: бактерии - инфузории / Е. А. Каретникова, А. Д. Жиркова // Известия РАН. Сер. биол. 2003. - № 1. - С. 101-109.

17. Корганова Г. А. Раковинные амебы (Testacea) почв Мещерской низменности / Г. А. Корганова, А. А. Рохлеева // Зоологический журнал. - 1997. - Т. 76, № 3. - С. 261-268.

18. Корганова Г. А. Раковинные корненожки (Protozoa, Testacida) как показатель почвенных условий // Итоги науки и техники. Зоология беспозвоночных. - Т. 5. - М.: Наука, 1978. С. $153-176$.

19. Колдунов А. А. Загрязнение территории Днепропетровска тяжелыми металлами / А. А. Колдунов, С. 3. Гендриховский // Экополис. - Д.: Арт-Пресс, 2002. - № 1 (11). - С. 47-48.

20. Латыпова В. 3. Оценка экологической токсичности осадков сточных вод / В. 3. Латыпова, С. Ю. Селивановская, Я.-Т. Ханг // Токсикологический вестник. - 1999. - № 3. - С. 13-17.

21. Мещеряков П. В. Трансформация экологических условий почвообразования и формирования гумусовых веществ под влиянием урбогенеза / П. В. Мещеряков, Е. В. Прокопович, И. Н. Коркина // Экология. - 2005. - № 1. - С. 11-19.

22. Місто Дніпропетровськ та екологічна ситуація в Дніпропетровській області // Экополис. Д.: Арт-Пресс, 2002. - № 1 (11). - С. 30-31.

23. Раковинные корненожки (Testacida) почв / Ю. Г. Гельцер, Г. А. Корганова, А. С. Яковлев, Д. А. Алексеев // Протозоология. - 1980. - № 5. - С. 108-142.

24. Селивановская С. Ю. Создание тест-системы для оценки токсичности многокомпонентных образований, размещаемых в природной среде / С. Ю. Селивановская, В. З. Латыпова // Экология. - 2004. - № 1. - С. 21-25.

25. Чугунов В. А. Создание и применмние жидкого препарата на основе ассоциации нефтеокисляющих бактерий / В. А. Чугунов, 3. М. Ермоленко, С. К. Жиглецова // Прикл. биохимия и микробиология. - 2000. - Т. 36, № 6. - С. 577-581.

26. Bobrov A. A. Testate amoebae (Protozoa, Testacea) of Russia and Canada as indicators of climatic changes in Holocene // Pub. Acad. Finl. - 1995. - P. 113-114.

27. Bobrov A. A. On the notion of mikrorange of soil testaceans // Biol. Bull. - 2003. - Vol. 30, N 1. - P. 87-94.

28. Testacea amoebae (Protozoa, Testacealobosea and Testaceafilosea) as bioindicators in the Late Quaternary deposits of the Bykovsky Peninsula, Laptev Sea, Russia / A. A. Bobrov, A. A. Andreev, L. Schirrmeister, C. Siegert // Paleogeography, Paleoclimatology, Paleoecology. - 2004. - Vol. 209. - P. 165-181.

29. Bonnet L. Quelques aspects des populations thécamoebiens endogées // Bull. Soc. Hist. Natur. Toulouse, 1959. - Vol. 94. - P. 413-428.

30. Bonnet L. L'émission pseudopodique, chez les thécamoebiens endogés // Bul. Soc. Zool. 1961. - N 86. - P. 17-28.

31. Bonnet L. Le peuplernent thécamoebien des sols // Rev. Ecol. Biol. Sol. - 1964. - Vol. 2. P. 123-408.

Вісник Дніпропетровського університету. Біологія, екологія.

Vìsnik Dnìpropetrovs'kogo unìversitetu. Seriâ Bìologîa, ekologîâ Visnyk of Dnipropetrovsk University. Biology, ecology. Vìsn. Dnìpropetr. Unìv. Ser. Bìol. Ekol. 2007. 15(1).

ISSN 2310-0842 print ISSN 2312-301X online www.ecology.dp.ua 
32. Bonnet L. Étude sur les thécamoebiens du sol / L. Bonnet, R. Thomas // Bull. Soc. Hist. Natur. Toulouse. - 1955. - Vol. 90. - P. 411-428.

33. Bonnet L. Thècamoebiens du sol / L. Bonnet, R. Thomas // Faune terrestre d'eau douce des Pyrénèes-Orientales. - 1960. - N 5. - P. 1-103.

34. Bonnet L. Types morphologiques, ecologie et evolution de la theque chei les Thècamoebiens // Protistologica. - 1975. - Vol. 11, N 3. - P. 363-378.

35. Coûteaux M.-M. Reconstitution d'une nouvelle communaute thecamoebienne dans la litiere d'une foret incendiee // Ecol. Bull. - 1977. - N 25. - P. 102-108.

36. Coûteaux M.-M. Dynamisme de l'equilibre des Thecamoebiens dans quelques sols climaciques // Mem. Mus. Nat. Hist. Nature. Ser. A. Zool. - 1976. - Vol. 96. - P. 183.

37. Charman D. J. Testate amoebae and the fossil record: issues in biodiversity // J. Biogeogr. 1999. - Vol. 26. - N 1. - P. 89-96.

38. Chardez D. Sur les Thecamoebiens des sols forrestiers du Sart-Tilman (Liege) // Bull. Inst. Agron. - 1962. - Vol. 30. - P. 263-272.

39. Chardez D. Ecologie generale des Thecamoebiens (Rhizopoda, Testacea) // Bull. Inst. Agron. 1965. - N 3. - S. 306-341.

40. Cowling A. J. Protozoa in the microbial communities of maritime Antarctic fellfields / A. J. Cowling H. G. Smith // Colloque sur les Ecosystemes Terrestres Subantarctiques. Paimpont.: CNFRA, 1987. - N 58. - P. 205-213.

41. Dunger W. Die Entwicklung der Bodenfauna auf rekultivierten Kippen und Halden des Braunkohlentagebaues // Abh. Ber. Naturkudemus. - 1968. - N 43. - 256 s.

42. Dunger W. The return of soil fauna to coal mined areas in the German Democratic Republic. Cambridge: Cambridge University Press, 1989. - P. 307-337.

43. Foissner W. Soil Protozoa: fundamental problems, ecological significance, adaptations in ciliates and testaceans, bioindicators, and guide to the literature // Progr. Protistol. - 1987. Vol. 2. - P. 69-212.

44. Foissner W. Soil Protozoa as bioindicators: pros and cons, methods, diversity, representative examples // Agric. Ecosyst. Environ. - 1999. - Vol. 74. - P. 95-112.

45. Foissner W. Soil Protozoa as bioindicators in ecosystems under human influence // Soil Protozoa CAB International. - 1994. - P. 147-193.

46. Foissner W. Stable for 15 million years: scanning electron microscope investigation of Miocene euglyphid thecamoebians from Germany, with description of the new genus Scutiglypha / W. Foissner, W. Schiller // Europ. Jour. Protistol. - 2001. - Vol. 37. - P. 167-180.

47. Foissner W. Redescription of three testate amoebae (Protozoa, Rhizopoda) from a Caucasian soil: Centropyxis plagiostoma Bonnet \& Thomas, Cyclopyxis kahli (Deflandre) and C. intermedia Kufferath // Archiv für Protistenkunde. - 1995. - Vol. 146. - P. 13-28.

48. Foissner W. The Centropyxis aerophila complex (Protozoa: Testacea) / W. Foissner, G. A. Korganova // Acta Protozool. - 2000. - Vol. 39. - P. 257-273.

49. Giller K. Toxicity of heavy metals to microorganisms and microbial processes in agricultural soils: a review / K. Giller, E. Witter, S. Mc Grath // Soil Biology \& Biochem. - 1998. - N 30. P. 138-141.

50. Jimenez J. J. Spatial distribution of earthworms in acid-soil savannas of the eastern plains of Colombia / J. J. Jimenez, J. P. Rossi, P. Lavelle // Appl. Soil Ecol. - 2001. - Vol. 17, N 3. P. 267-278.

51. Lousier J. The disappearance of the empty tests of litter- and soilvamoeba (Testacea, Rhizopoda, Protozoa) / J. Lousier, D. Parkinson // Archiv für Protistenkunde. - 1981. Vol. 124. - P. 312-336.

52. Olschowy G. Bergbau und Landshaft. Rekultivierung durch Landschaftspflege und Landschaftsplanung. - Hamburg: Prey, 1993. - 215 s.

53. Pflug W. Braunkohlentagebau und Rekultivierung. Landschaftökologie-FolgenutzungNaturschutz. - Berlin: Springer, 1998. - S. 1068-1075.

54. Rakhleeva A. A. To the estimation of shell amoeba (Rhizopoda, Testacea) population and species diversity in taiga soils / A. A. Rakhleeva, G. A. Korganova // Zool. Jour. - 2005. Vol. 84, N 12. - P. 1427-1436.

Вісник Дніпропетровського університету. Біологія, екологія.

Vìsnik Dnìpropetrovs'kogo unìversitetu. Serìa Bìologiâ, ekologîâ Visnyk of Dnipropetrovsk University. Biology, ecology. Vìsn. Dnìpropetr. Unìv. Ser. Bìol. Ekol. 2007. 15(1).

ISSN 2310-0842 print ISSN 2312-301X online www.ecology.dp.ua 
55. Schönborn W. Beschalten Amoben (Testacea). - Wittenberg Lutherstadt: Ziemsenverlag, 1966. $-112 \mathrm{~s}$.

56. Schönborn W. Taxoinotik der beschalten sudwasser Rhkopoden. Eine raumslruitturanalytische Untersuchung uber Lebensraumerweiterung und Evolution bei dec Microfauna // Limnologica. 1967. - Bd. 5. - S. 159-207.

57. Schönborn W. Paläolimnologische studien an Testaceen aus Bohrkernen des Latnjajaure (Abisko-Gebiet; Schwedisch-Lappland) // Hydrobiologia. - 1973. - Bd. 42. - S. 63-75.

58. Schönborn W. Ermittlung der Jahresproduktion von Boden-Protozoen. Euglyphidae (Rhizopoda, Testacea) // Pedobiologia. - 1975. - Vol. 15. - S. 415-424.

59. Schönborn W. Adaptive polymorphism in soil-inhabiting testate amoebae (Rhizopoda): its importance for delimination and evolution of asexual species // Arch. Protist. - 1992. Vol. 142. - P. 139-155.

60. Schönborn W. Comparative studies on the production biology of protozoan communities in freshwater and soil ecosystems // Arch. Protist. - 1992. - Vol. 141. - P. 187-214.

61. Smith H. G. The colonization of volcanic tephra on Deception Island by protozoa: Long term trends // Br. Antarct. Surv. Bull. - 1985. - Vol. 66. - P. 19-33.

62. Smith H. G. Testateamoebae - past, present and future / H. G. Smith, S. Coupe // Europ. Jour. Protistol. - 2002. - Vol. 37. - P. 367-369.

63. Die Anpassung der Mikroflora und Mikrofauna an die Vcrhaltnisse der Siikboden / A. Szabo, M. Marlon, A. Szaboles, L. Varga // Acta agron. Acad. Sci. Hung. - 1959. - N 2. - S. 9-38.

64. Stout J. The protozoan fauna of a seasonally inundated soil under grassland // Soil. Biol. \& Biochem. - 1984. - Vol. 16, N 2. - P. 121-125.

65. Global change, soil biodiversity, and nitrogen cycling in terrestrial ecosystems: three case studies / M. J. Swift, O. Andren, L. Brussard et al. // Glob. Change Biol. - 1998. - Vol. 4, N 7. P. 72-743.

66. Tabatabai M. Effects of trace elements on urease activity in soil // Soil Biology \& Biochem.1976. - Vol. 14, N 9. - P. 9-13.

67. Tsyganov A. Morphology, biometry and ecology of Arcella gibbosa Penard, 1890 (Rhizopoda, Testacealobosea) / A. Tsyganov, Y. Mazei // Protistology. - 2006. - Vol. 4 (3). - P. 279-294.

68. Vasseur P. Interactions between copper and some carbamates used in phytosanitary reatments / P. Vasseur, D. Dive // Chemosphere. - 1988. - Vol. 17. - P. 767-782.

69. Waggoner B. M. The first fossil cyphoderiid testate amoeba, in Dominican Republic amber (Eocene-Oligocene) // PaleoBios. - 1996. - Vol. 17. - P. 17-19.

70. Waggoner B. M. Bacteria and protists from Middle Cretaceous amber of Ellsworth County, Kansas // PaleoBios. - 1996. - Vol. 17. - P. 20-26.

71. Wanner M. Zur morphologie von Thekamöben (Protozoa, Rhizopoda) in süddeutschen Wäldern // Arch. Protist. - 1991. - N 140. - S. 45-66.

72. Wanner M. Immigration and primary succession of protists (testate amoebae) on recultivated lignite mine spoils in Eastern Germany / M. Wanner, W. Dunger // Verh. Ges. Ökol. - 1999. N 29. - P. 321-327.

73. Wanner M. Effects of some environmental factors on the shell morphology of testate amoebae (Rhizopoda, Protozoa) / M. Wanner, R. Meisterfeld // Europ. J. Protistol. - 1994. - Vol. 30. P. 191-195.

74. Wolf M. Verkieste Amöben in Steinkohlen aus dem Ruhrgebiet - erster Nachweis von Arcella // Ehren. Paläoz. Paläont. - 1995. - Z. 69. - S. 1-6.

Надійшла до редколегії 03.12.2006

Вісник Дніпропетровського університету. Біологія, екологія.

Vìsnik Dnìpropetrovs'kogo unìversitetu. Seriâ Bìologîa, ekologiâ

Visnyk of Dnipropetrovsk University. Biology, ecology. Vìsn. Dnìpropetr. Unìv. Ser. Bìol. Ekol. 2007. 15(1).

ISSN 2310-0842 print ISSN 2312-301X online www.ecology.dp.ua 